\title{
Effect of marine feed additions on the digestibility of poultry nutrients
}

\author{
Zoya Tsoy $^{1, *}$, Yuri Nikulin ${ }^{2}$, and Olga Nikulina ${ }^{3}$ \\ ${ }^{1}$ Primorsky State Agricultural Academy, 44, Blukhera prospect, 692525, Ussuriisk, Russia
}

\begin{abstract}
Poultry farming is one of the most important branch of animal husbandry. Poultry is very sensitive to a lack of protein, vitamins, microelements and macroelements. The lack of these substances is very bad for the health, development, growth and productivity of poultry. Primorsky Krai is rich in seafood, which is extracted in large quantities. In the process of processing seafood, a large amount of waste remains, which could be used for feed purposes, for feeding farm animals and poultry. The use of seafood waste would solve the problem with a nutrient deficiency in the diets of poultry. The digestibility of feed nutrients is a secondary indicator of their nutritional value. The better the nutrients are digested in the animal's body, the more nutritious the food is. In our research work, we studied the influence of marine hydrobionts on the digestibility of dietary nutrients.
\end{abstract}

\section{Introduction}

One of the factors that influence on the development of animal husbandry, and in particular poultry farming, is the inferiority of the feed base. Poultry farming in the Far East is not only lacking protein, but also vitamins and trace elements and amino acids. The Far East is rich in various marine hydrobionts, which are rich in protein, essential amino acids, vitamins, and trace elements. Various shellfish, fish, shrimps, krill and other products are extracted and processed on the territory of the region. Waste from the processing of marine hydrobionts can be used as a feed addition. In the Primorye territory, sea silt, corbicula japonica, seashells, spirulina, seaweed, sea urchins, crustaceans, squid, Leda flour, and others were used to increase the nutritional value of compound feeds.

Digestibility of feed is one of the most important indicators of its value. Animals and only with the part of the feed that they can digest. Undigested feed substances are released from the body. The digestibility of feed nutrients varies greatly depending on the heredity of animals, their condition, as well as on the properties of feed and feeding techniques.

The digestibility of feed is by no means a constant value, it depends on various factors, such as the type of animals, the amount of feed, the composition of the diet and the preparation of feed. The biggest differences between animal species are observed in raw fiber. Ruminants are far superior to pigs in their ability to digest feed rich in raw fiber. The amount of raw fiber consumed by animals is affected not only by the digestibility of raw fiber, but also by the digestibility of other nutrients.

* Corresponding author: zoyatsoy84@mail.ru 
Digestibility is affected by the type, age, and personality of the animal. Because of the differences in the structure and functions of the digestive system, the same food is digested differently by animals of different species. Even among ruminants, there are differences. Cattle digest roughage better than sheep. They are significantly inferior to ruminants in their ability to digest coarse feed from horses and even more from pigs. Poultry digests food worse than other farm animals.

The digestibility is influenced by the nature of feeding during growth, the amount, properties and composition of the feed, as well as the multiplicity and timeliness of feeding, the variety of diets, the order of feeding feeds, the ratio of nutrients in the diet, the animal's aphit, the presence of vitamins, etc. In addition, one-hundred-year excess or lack of nutrients in the diet affects the digestibility. [1-5]

Of the individual nutrients, protein and fiber have the greatest impact. The more fiber in the feed, the lower the digestibility of all its nutrients. In ruminants, normal digestion of feed is possible if 8-10 parts of digestible nitrogen-free substances, including fat multiplied by 2.25 , account for at least one part of the digestible protein. With a wider protein ratio, there is a decrease in the digestibility of carbohydrates and protein. The reason for the deterioration of digestibility with a lack of protein in the feed is a decrease in the secretion of digestive glands and changes in the microbiological processes in the digestive canal.

Digestibility is a very important indicator of feed value. [6-15]

The digestibility of the feed affects its energy content. Therefore, often in order to determine how much energy is contained in the feed, you need data on the digestibility of its individual raw substances (organic mass, raw protein, raw fat, etc.).

The purpose of the research is to study the effect of marine feed meal on the digestibility of nutrients of poultry.

\section{Research methods}

The object of the study was hens of Haysex White cross. To conduct a physiological experiment, we selected 12 heads of laying hens using the method of analogues. During the experiment, all the livestock were in the same conditions. The physiological experience consisted of two periods: the first period (preparatory) lasted 7 days, the second period of experience, called the accounting period, and lasted a total of 5 days. During the balance experiment, we took into account the amount of feed and water consumed by the bird per day, as well as the amount of excreted droppings. The litter was collected 2 times a day.

Hens were divided into four groups (control and three experimental) of 3 heads each. The physiological experiment was performed according to the methodology presented in table 1 .

Table 1. Scheme of research work

\begin{tabular}{|l|l|l|l|l|}
\hline Feed complex & Group & $\begin{array}{l}\text { Length of } \\
\text { research }\end{array}$ & $\begin{array}{l}\text { Amount of } \\
\text { poultry }\end{array}$ & Diet \\
\hline \multirow{2}{*}{$\begin{array}{l}\text { Marine } \\
\text { meal feed }\end{array}$} & control & $7 / 5$ days & 3 & $\mathrm{BR}$ \\
\cline { 2 - 5 } & I experimental & $7 / 5$ days & 3 & $\mathrm{BR}+3 \%$ \\
\cline { 2 - 5 } & II experimental & $7 / 5$ days & 3 & $\mathrm{BR}+5 \%$ \\
\cline { 2 - 5 } & III experimental & $7 / 5$ days & 3 & $\mathrm{BR}+7 \%$ \\
\hline
\end{tabular}

*BR - Basic ration (diet)

\section{Results}


We account feed and feces every day. Based on the actual consumption of feed and excreted feces, we determined the coefficients of digestibility of feed nutrients for control and I, II, III experimental groups of poultry. The results of the balance experience are presented in table 2 .

Table 2. Digestibility of nutrients of hens, $\%$

\begin{tabular}{|l|l|l|l|l|}
\hline \multicolumn{1}{|c|}{ Group } & $\begin{array}{l}\text { Organic } \\
\text { matter }\end{array}$ & Fat & Protein & Fiber \\
\hline control & 76,5 & 66,5 & 80,9 & 12,0 \\
\hline I experimental & 78,3 & 68,1 & 81,6 & 13,0 \\
\hline II experimental & 78,7 & 68,9 & 84,2 & 13,5 \\
\hline III experimental & 78,8 & 69,7 & 86,7 & 14,0 \\
\hline
\end{tabular}

Digestibility of nutrients of hens are present in figure 1.

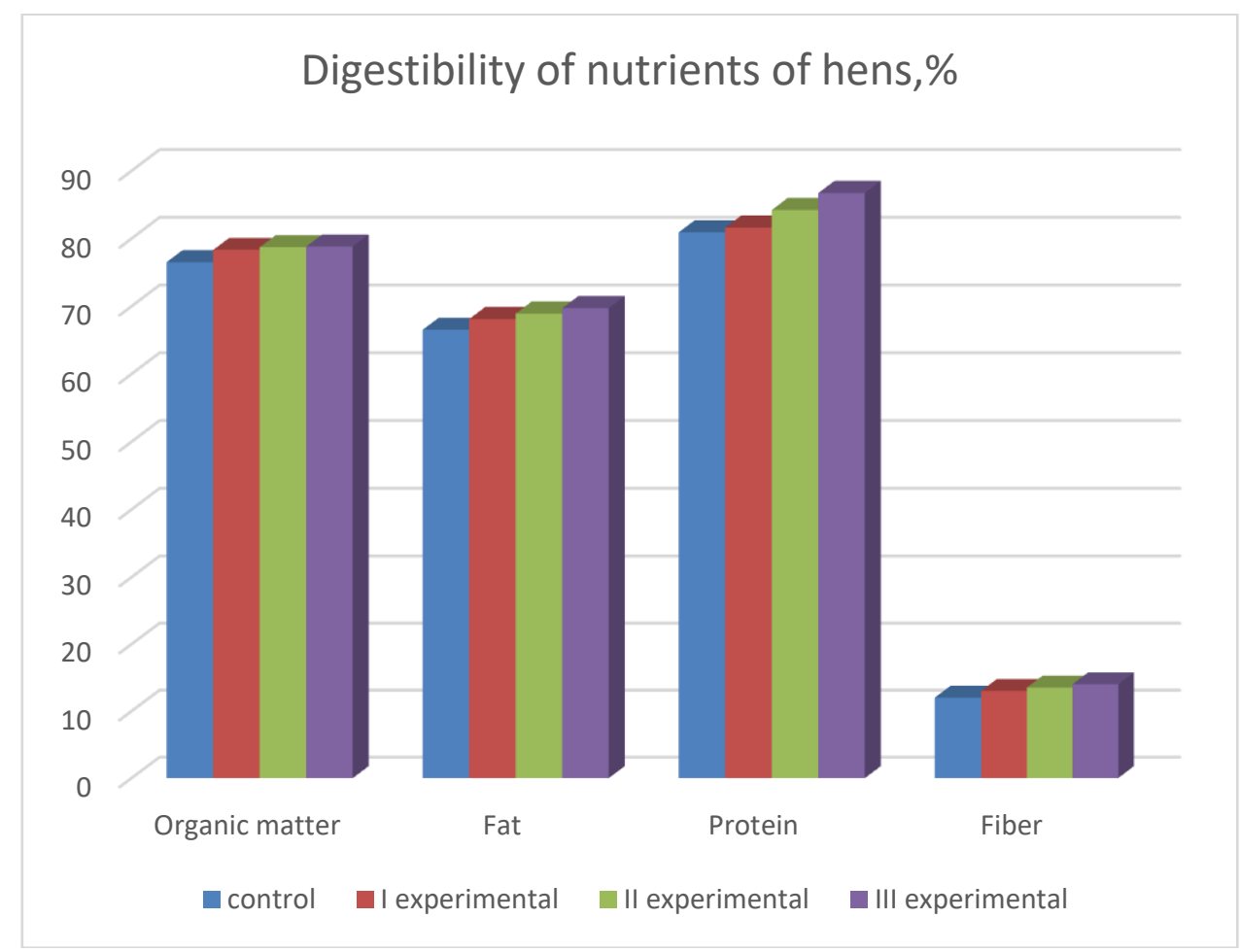

Fig. 1. Digestibility of nutrients of hens, $\%$

The digestibility indexes in I, II, III experimental groups were higher than in the control group. Thus, the index of digestibility of organic matter was higher by $1.8-2.3 \%$, fat-1.6$3.2 \%$, protein- $0.7-5.8 \%$ and fiber- $1.0-2.0 \%$. The best index for the digestibility of nutrients were in III experimental group, where poultry received marine feed meal at a dose of $7 \%$.

A similar results are observed with young poultry. During the physiological experiment, the best index were obtained in the III experimental group, which received $7 \%$ of the feed meal (table 3).

Table 3. Digestibility of nutrients of young poultry, $\%$

\begin{tabular}{|l|l|l|l|l|}
\hline Group & Organic & Fat & Protein & Fiber \\
\hline
\end{tabular}




\begin{tabular}{|l|l|l|l|l|}
\hline & matter & & & \\
\hline control & 69.4 & 69.9 & 85.0 & 14.8 \\
\hline I experimental & 72.5 & 74.3 & 87.2 & 16.5 \\
\hline II experimental & 73.2 & 75.1 & 88.6 & 16.6 \\
\hline III experimental & 74.3 & 75.3 & 88.8 & 16.7 \\
\hline
\end{tabular}

Digestibility of nutrients of young poultry is shown in figure 2 .

\section{Digestibility of nutrients of young poultry, $\%$}

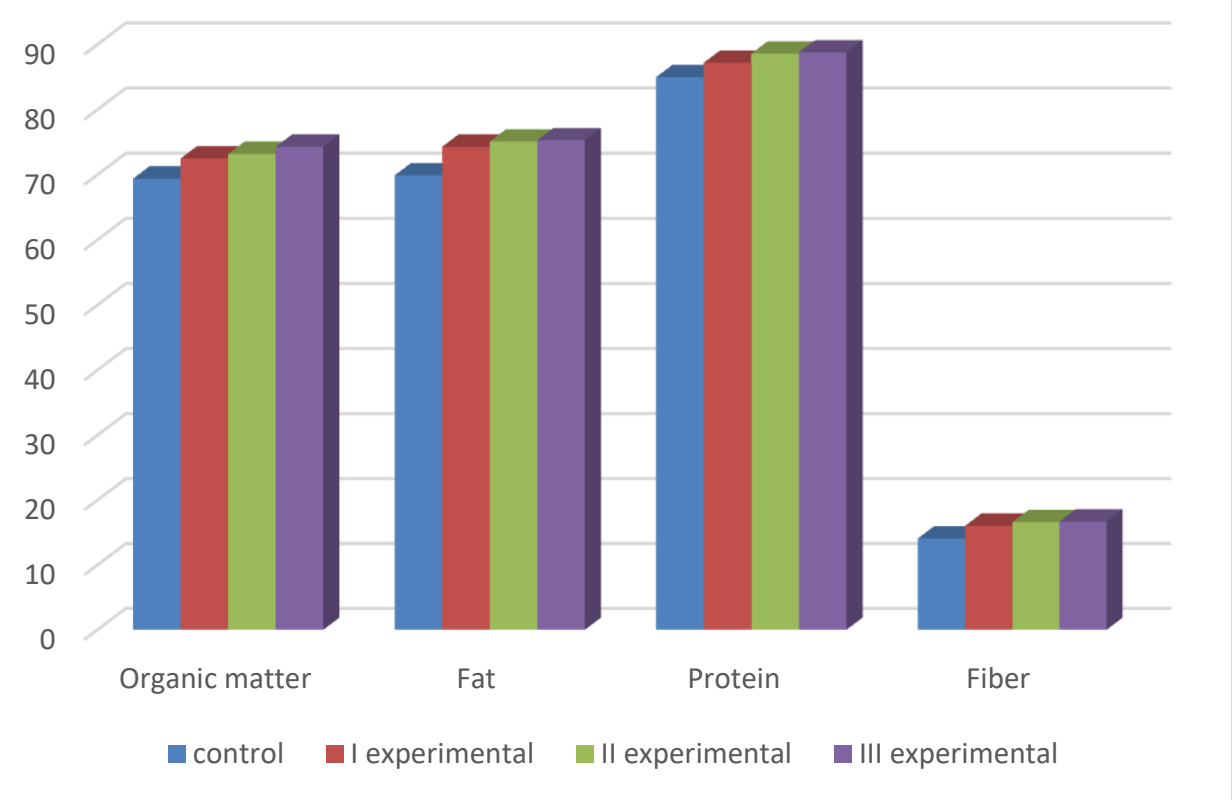

Fig. 2. Digestibility of nutrients of young poultry, $\%$

Young poultry of the control group had a higher index. The digestibility indexes in I, II, III experimental groups were higher than in the control group. The index of digestibility of organic matter was higher by $3.1-4.9 \%$, fat- $4.4-5.4 \%$, protein- $2.2-3.8 \%$ and fiber- $1.7-1.9 \%$. The best index for the digestibility of nutrients were in III experimental group, where poultry received marine feed meal at a dose of $7 \%$.

The maximum difference between the experimental group and the control was observed for fat and was $5.4 \%$.

We have studied the effect of feed additives on the absorption and balance of nitrogen, calcium and phosphorus. The results are shown in table 4.

Table 4. Assimilation and balance of nitrogen, calcium and phosphorus, $\%$

\begin{tabular}{|l|c|c|c|c|}
\hline \multirow{2}{*}{ Indicator } & \multicolumn{4}{|c|}{ Group } \\
\cline { 2 - 5 } & control & I & II & III \\
\hline
\end{tabular}




\begin{tabular}{|l|c|c|c|c|}
\hline & & experimental & experimental & experimental \\
\hline Taken with feed, g: & & & & \\
nitrogen & 3,1 & 3,1 & 3,1 & 3,1 \\
calcium & 3,1 & 3,1 & 3,1 & 3,1 \\
phosphorus & 0,7 & 0,7 & 0,7 & 0,7 \\
\hline Contained in excrements, & & & & \\
g: & 1,5 & 1,3 & 1,4 & 1,3 \\
nitrogen & 1,9 & 1,7 & 1,6 & 1,6 \\
calcium & 0,25 & 0,25 & 0,25 & 0,2 \\
phosphorus & & & & \\
\hline Assimilated, g: & & & & 1,9 \\
nitrogen & 1,6 & 1,8 & 1,9 & 1,4 \\
calcium & 1,2 & 1,4 & 1,5 & 0,5 \\
phosphorus & 0,45 & 0,45 & 0,45 & \\
\hline
\end{tabular}

Assimilation of nitrogen, calcium and phosphorus are shown in figure 3.

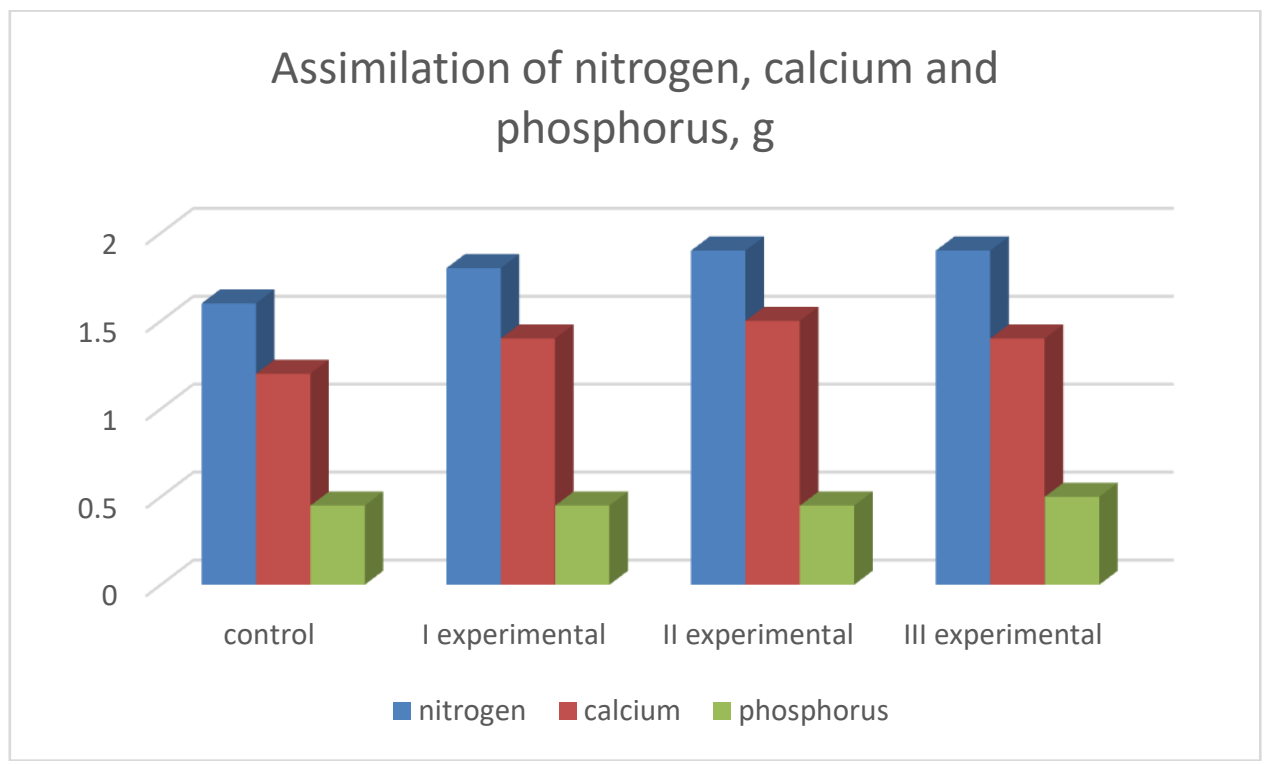

Fig. 3. Assimilation of nitrogen, calcium and phosphorus, $g$

After conducted balance experiment we established that the highest coefficients of nitrogen and calcium assimilation were obtained by chickens of the experimental groups. Chickens of the II experimental group showed the maximum absorption of calcium. Data shows that the marine feed meal has a positive effect on the use and absorption of nitrogen. In the body of chickens of the III experimental groups was deposited more phosphorus $(0.5$ $\mathrm{g}$ ) and differ between control and III experimental group was $0.05 \mathrm{~g}$.

The analysis of the obtained data shows that the marine feed meal at a dose of $7 \%$ for laying hens and for young hens of the cross Hayssex White has a positive effect not only on the balance, assimilation, but also on the deposition of nitrogen, calcium and phosphorus in the body.

Based on the conducted research work and results of the balance experience, we have established a positive effect of marine feed meal on the digestibility of nutrients, assimilation, balance of nitrogen, calcium and phosphorus. The digestibility of organic matter, protein, fat, and fiber in the experimental group was higher than in the control 
group. The greatest superiority was observed in the II and III experimental group. The best using of calcium, phosphorus and nitrogen was also observed in the experimental group, which was fed a feed additive at a dose of $7 \%$ for laying hens and for young animals.

\section{References}

1. G. Dibaibee, Poultr. Sci., 5(1), 7-15 (2017)

2. J. J. Powell, N. Faria, E. Thomas-McKay, L. C. Pele, Origin and fate of dietary nanoparticles and microparticles in the gastrointestinal tract Journal of Autoimmunity. 34(3), 226-233 (2010) doi: https://doi.org/10.1016/j.jaut.2009.11.006. Epub 2010. Jan 21.

3. A. Aghaei, Poultr. Sci., 5(1), 57-64 (2017)

4. R. Gornati, E. Pedretti, F. Rossi, F. Cappellini, M. Zanella, I. Oliveto, E. Sabbioni, G. Bernardini, Tolerance to the nanoparticles zerovalent $\mathrm{Fe}, \mathrm{Co}$ and $\mathrm{Ni}$, evaluated on the cell lines SKOV-3 and U87 Journal of Applied Toxicology, 36(3), 385-393 (2016) doi: 10.1002 / jat.3220.

5. V. A. Ryzhkov, Research and Technical Advances of Agribusiness Sector, 5, 36-37 (2017)

6. T. N. Lenkova, T. A. Egorova, Ptakhivnistvo (Mezhvidomchii tematichnii naukovii zbimik)), Poultry farming, 68, 281-283 (2012)

7. Z. V. Tsoy, D. S. Adushinov, Corbicula flour influence on egg production. IOP Conference Series: Earth and environmental science (EES), 548(2) (2020) doi:10.1088/1755-1315/548/2/022017

8. S. I. Kononenko, 9 International Symposium of Animal Biology and Nutrition 22 (2010)

9. R. Majidzaden Heravi, Poultr. Sci., 4(2), 107-116 (2016)

10. Z. V. Tsoy, N. V. Vasileva, Untraditional feeds influencing on poultry growth. IOP Conference Series: Earth and environmental science (EES), 548(7) (2020) doi:10.1088/1755-1315/548/7/072007

11. M. Fathi, Poultr. Sci., 4(2), 139-146 (2016)

12. S. I. Kononenko, Physiological and biochemical status of the body of a broiler chicken when improving the processing technology of feed grain. Polythematic network electronic scientific journal of the Kuban State Agrarian University, 84, 482-491 (2012)

13. S. I. Kononenko, Ways of improvement of protein nutritional value in compound feeds. Polythematic network electronic scientific journal of the Kuban State Agrarian University, 81, 520 - 545 (2012)

14. Z. V. Tsoy, CIS-Korea Conference of Science and Technology, 76-83 (2015)

15. Z. V. Tsoy, Global Journal of Biotechnology \& Biochemistry, 8(4), 74-77 (2013)

16. R. L. Sharvadze, EurAsian Journal of BioSciences Eurasia J Biosci., 1(12), 143-148 (2018) 